Е. Е. Машкова

Силфберополь

DOI: 10.15393/j9.art.2011.327

\section{«ДВОЕВЕРИЕ» СОВЕТСКОЙ ЭПОХИ В «ПРОИЗВОДСТВЕННОЙ» ПРОЗЕ 1920-1930-x ГОДОВ}

$\mathrm{B}$

1929 году в одном из материалов «Комсомольской правды» приводилось мнение авторов некоего английского издания о природе большевистской идеологии, согласно которому еще не существовало «религиозного движения», прививающего молодежи «свои принципы веры» «с такой энергией», «как это делает коммунистическая партия в России»: подрастающее советское поколение «приучают не только исповедовать новую политическую веру, но и гореть этой верой и быль готовыли бороться $и$ улереть за нее» ${ }^{1}$. Примечательно, что выдержка давалась без обычных в таких случаях комментариев-опровержений, хотя Сталиным резко пресекались всякие разговоры о «примирении» Советов с православной церковью, об «использовании» церкви в интересах коммунистов ${ }^{2}$.

Мысль о вероисповедной природе русской револющии начали высказывать задолго до ее победы. Уже в 1909 году Н. Бердяев писал о том, что фрилософрия экономического материализма в России превратилась в классовую проле-

(C) Машкова Е. Е., 2011

${ }^{1}$ Канатчиков С. О судьбах попутничества // Красная новь. 1929. Кн. 11. С. 211. Здесь и ниже, кроме специально оговоренного случая, курсив наш.

${ }^{2}$ Сталин И. Сочинения. Т. 10. М.: Госполитиздат, 1949. С. 373-374 тарскую мистику, в 1930-е годы большевизм («не как социальная система, а как религия») стал предметом всестороннего анализа философра в работе «Истоки и смысл русского коммунизма $»^{3}$. В перестроечную эпоху именно в этом ключе проходило переосмысление советской литературы. Исследователи искали и в изобилии находили в ней примеры параллелей со Священным Писанием, с православной системой ценностей. Со временем подход стал более диалектичным: литературоведы не только констатируют аналогии с православием, на которых строилась новая советская вера, но и обращают внимание на «механизмы замещения» христианства коммунизмом, указывают на полярно противоположный православному характер второго 4 . Вместе с тем и сегодня среди трех источников «творчества» «писателя» Сталина называется православная традиция ${ }^{5}$. Таким образом, вопрос о вероисповедной партийности остается открытой проблемой для всех гуманитариев, и в том числе для литературоведов, поскольку сакрализация партийной догматики была главной фрункцией социалистического реализма ${ }^{6}$.

Наиболее репрезентативным явлением соцреализма по праву считаются романы, повести, рассказы и очерки, посвященные индустриализации СССР, так называемая «производственная» проза. Стилистике «производственных» романов особенно свойственны христианские литургические формулы, библеизмы, евангельские сюжеты, направленные на сакрализацию начатых властью преобразовательных процессов. В «индустриальной» прозе создавался советский миф о сотворении мира. Своеобразным штампом этой литературы стало рождение прямо из "ничего» завода, промышленного города или поселка: пять, десять лет назад

${ }^{3}$ Подробнее об эволюции взглядов Н. Бердяева на русский большевизм как религиозное учение см.: Волконогова $O$ Д. Н. А. Бердяев. Интеллектуальная биография. М., 2001.

${ }^{4}$ Есаулов И. А. Категория соборности в русской литературе. Петрозаводск: Изд-во ПетрГУ, 1995. С. 166, 172, 174.

${ }^{5}$ Baйскопф M. Писатель Сталин. М.: Новое литературное обозрение, 2002. С. $127-131$.

${ }^{6}$ Дунаев М. М. Православие и русская литература: В 6 т. Т. 4. М.: Христианская литература, 2000. С. 9. 
на их месте были глушь или пустыня. На библейском рефрене «И был вечер, и было утро...» (Быт. 1:5-23) строится описание жизни коммуны в «Новой земле» Ф. Гладкова? Но самый яркий пример в этом контексте - конечно, повесть И. Эренбурга о строительстве Кузнецкого комбината «День второй», которую современники писателя называли еще «Вторым днем творения» ${ }^{8}$.

В мифе, утверждаемом соцреализмом, творцами нового мира и нового человека делаются Сталин, большевики и рабочие. Собирательный образ партии, создающей «простых и неутомимых» людей «по образу своему и подобию», прозрачно выписан в эталонном тексте соцреализма истории строительства Беломорско-Балтийского канала' Особо популярными были сравнения рабочего, пролетария, производственника с кощунственно низводимым Образом Небесного Творца, что наглядно иллюстрирует очерк Ник. Брыкина «Провинциальная идея» (1934). Автор рисует героя, приступающего к изготовлению тиглей «по примеру того лысого библейского старичка, который, по словам «очевидцев», в шесть дней создал твердь, людей, растения и всякую большую и малую, ласковую и злую тварь на земле и воде» ${ }^{10}$.

«Производственный» жанр отражает изменения духовного облика страны. Завод в «производственной» прозе ста-

${ }^{7}$ Гладков Ф. Новая земля // Гладков Ф. Собр. соч. Т. 4. М.: Худож. лит., 1931. 288 с. С. 131, 276.

8 Попов В., Фрезинский Б. Илья Эренбург: Хроника жизни и творчества. Т. 3. СПб.: БАН, 2001. С. 114. Критики также отмечали библейско-космогонический пафос "Дня второго» (Попов В., Фрезинский Б. Илья Эренбург: Хроника жизни и творчества. Т. 3. СПб.: БАН, 2001. C. 122, 220; Селивановский А. День третий? // Знамя. 1935. № 9. С. 216) В 1960-е годы исследователи «вспомнили» о том, что «заглавие романа... эпическая ритмика фраз, также невольно вызывавшая в памяти неторопливую речь библейских сказаний, и множество персонажей, сменявших друг друга с непривычной пестротой... “удивляли" советского читателя» (Эренбург И. Г. День второй // Эренбург И. Г. Собр. соч. В 9 т. Т. 3. М., 1964. С. 500).

${ }_{9}$ Беломорско-Балтийский канал имени Сталина. История строительства. 1931-1934 гг. / Текст ред. М. Горького, Л. Авербаха, С. Фирина. M., 1998. C. 548.

${ }^{10}$ Брыкин Н. Провинциальная идея // Звезда. 1934. № 7. С. 147180. C. 147. новится культовой постройкой, замещающей православные храмы не только в переносном смысле, но и буквально. В 1925 году в «Цементе» Ф. Гладков прямо называет завод храмом. О том же пишет и И. Эренбург: советские города растут вокруг заводов, «как некогда... вокруг чтимых народом соборов» ${ }^{11}$. Развалины церкви, монастыря или часовни становятся устойчивой деталью пейзажа «индустриальных» романов. В «Дне втором» Эренбурга, повести Б. Пильняка «Волга впадает в Каспийское море», «Скутаревском» Леонова разрушенная, оскверненная церковь (в «Соти» - вымирающий скит) - фон, на котором ударными темпами разворачивается производство ${ }^{12}$.

В повести И. Эренбурга «Не переводя дыхания» описывается, как из кирпичей Томского кафедрального собора строят институт и баню в Архангельске; как в Тотьме в церкви устраивают клуб; сжигают старинные церкви уникальные памятники деревянного зодчества Русского Севера $^{13}$. В «Беломорско-Балтийском канале им. Сталина» на кресты «старой Карелии» натягивают провода «как знамя социалистического наступления» ${ }^{14}$. В «Мужестве» В. Кетлинской на церковной паперти чистят картошку. В «Трагедии Любаши» Ф. Гладкова разрушение колоколен, снос купола храма Христа Спасителя перечисляются в одном ряду с производственными достижениями героев ${ }^{15}$. Этот принцип сохраняется и в произведениях об индустриальном освоении Советского Востока, с той лишь разницей, что там уничтожаются памятники мусульманства. В «Романе межгорья» И. Ле в ходе строительства оросительной системы Голодной степи закрывают мусульманскую обитель ${ }^{16}$, в романе Б. Ясенского «Человек меняет кожу» большевикам для проведения канала «пришлось разворочать святую гор-

11 Эренбург И. Г. День второй // Эренбург И. Г. Собр. соч.: В 9 т. Т. 3. M., 1964. C. 155 .

12 Пильняк Б. Повесть непогашенной луны: Сборник. М.: Кн. палата, 1989. С. 159; Леонов Л. Собр. соч.: В 10 т. М.: Худож. лит., 1970. Т. 4. C. $10-11$.

13 Эренбург И. Г. Не переводя дыхания // Эренбург И. Г. Собр. соч.: В 5 т. T. 4. M., 1953. С. 236-237, 280.

${ }^{14}$ Беломорско-Балтийский канал имени Сталина. С. 154.

${ }^{15}$ Гладков Ф. Трагедия Любаши // Новый мир. 1935. Кн. 1. С. 31.

${ }^{16}$ Ле И. Роман межгорья. Киев: Дніпро, 1986. С. 610. 
ку», на которой находилось кладбище с мусульманскими святыми ${ }^{17}$.

Но, несмотря на то что альтернатива «завод - храм» утверждалась в литературе более чем настойчиво, партийным и литературным вождям этого, по-видимому, было недостаточно. В 1934 году на первом Всесоюзном съезде советских писателей М. Горький призывает литераторов больше говорить о том, что в Советском Союзе над селами и уездными городами возвышается уже «не церковь, а... гигантские фрабрики» ${ }^{18}$.

Духовная ситуация в советском обществе 1920-1930-х годов в «производственной» прозе отозвалась не просто поношением православия и пафросом рождения новой советской веры, но и вылилась в мотив «соревнования» вер. Никак иначе не назовешь изображенную И. Эренбургом в «Дне втором» борьбу «на выбывание» христианства, иудейства, язычества и религии страны Советов в сердцах и умах жителей Кузнецкстроя. В Томске лишенцы, «прикрыв плотно ставни, зажигали лампадки перед иконами», а пионеры пересказывали верующим родителям уроки безбожия ${ }^{19}$. Старый раввин «молился своему злому и ненавистному Богу», а его пятилетний сын Йосик не считал еврейскую Пасху праздником:

...он хотел вместе с другими ребятами ходить по городу и махать фрлагом ${ }^{20}$.

Дети шорцев не верили в деревянных богов и волшебную силу шаманов. А профрессор Плихтер, читая в Иене лекцию о верованиях сибирских народов, «вдруг... сказал невпопад: “...все население Советской России, включая даже передовые умы, охвачено мистицизмом, который абсолютно непонятен для европейского сознания"» ${ }^{21}$. В повести Ф. Гладкова «Новая земля» учитель Прохор пропаганду

17 Ясенский Б. Человек меняет кожу. М.: Сов. писатель, 1956. С. 449.

18 Первый Всесоюзный съезд советских писателей: Стенографический отчет. М., 1934. С. 14.

19 Эренбург И. Г. День второй. С. 181.

20 Там же. С. 183.

21 Там же. С. 260. на селе воспринимает как богоборческое состязание, где основной соперник - «овинный и голодный бог мужика» ${ }^{22}$

Главная схватка в «Романе межгорья» И. Ле разворачивается не между людьми и природой за воду в Голодной степи, а между большевиками и мусульманской обителью за душу каждого дехканина. В «Соти» Увадьев, считавший себя «испытанным ловцом человеков» ${ }^{23}$, переманивает в советский лагерь монаха Геласия. Когда тот приходит к Увадьеву грязный, больной, в сыпи, Увадьев не просто заставляет его вымыться - поливая водой бывшего скитника, намазывая ему лоб йодом, он совершает над ним глумливый обряд крещения:

Ну, вот и крестили парня в новую веру ${ }^{24}$.

Увадьев, конечно, шутит. Но современница эпохи М. Шагинян в книге «Человек и время» приводила многочисленные примеры новой обрядности, альтернативной церковной: крестины заменялись октябринами, отпевание умершего похоронным маршем и т. д. Осознавая, что «церковный обряд в русском народе прижился почти бессознательно», говорит М. Шагинян, большевики, «чтобы насытить потребность обряда у народа», создавали «искусственные обряды» ${ }^{25}$. Писательница в данном случае раскрывает самый механизм создания партийной веры, которая по форме ничего принципиально нового не предлагала. Литература отразила слияние в народном сознании большевизма и православия на первом этапе образования новой советской веры. Производственная проза в полной мере воспроизводит ситуацию своеобразного советского «двоеверия» ${ }^{26}$, сложившуюся в стране в 1920-1930-е годы.

${ }^{22}$ Гладков Ф. Новая земля. С. 232.

23 Леонов Л. Собр. соч.: В 10 т. М.: Худож. лит., 1970. Т. 4. С. 241

24 Там же. С. 457.

${ }^{25}$ Шагинян М. С. Человек и время. История человеческого становления. М.: Худож. лит., 1980. С. 430—431.

26 Двоеверие «присуще каждому этапу развития человеческой культуры, когда совершается переход от одной духовно-интеллектуальной формации к другой» (Филиппов $Г . Г . К$ проблеме двоеверия. Историографический анализ // Вестник новгородского государственного университета. 2004. № 27. С. 96). Как двоеверие определяется состояние советского общества 1920-1930-х годов в работах Ю. Степанова, В. Па- 
По свидетельству авторов истории Беломорско-Балтийского канала, у штаба строительства (станции, похожей на деревянную церквушку) богомольные приезжие крестились ${ }^{27}$. Молодоженов «благословляют по-комсомольски» в «Мужестве» В. Кетлинской. В самый кульминационный момент повести И. Эренбурга «День второй» - в преддверии Первого мая - рабочие пекут куличи, как к Пасхе ${ }^{28}$. Еще наглядней народное двоеверие проявляет крестьянская проза. Вот как напостовец Деревенский пересказывает рассказ М. Волкова «Чудо», героиня которого нашла листок с портретом Карла Маркса:

Богомольная бабушка приняла его за угодника... затеплила лампадку перед ним, стала просить его, чтобы помог избенку соблюсти. А в эту ночь зашел к старухе ночевать красноармеец, узнал, что бабушка Карлу Марксу молится... и, чтобы сохранить в бабушке веру в нового угодника, исполком на свои средства... поправил избенку.

После чего бабушка сказала: «Христос воскресе!»»29. Народ в советской литературе вообще живет по двойному советско-православному - календарю: в повести И. Катаева «Ленинградское шоссе» старик Савва Пантелеевич умирает «в канун первого мая, в ночь на страстную субботу» ${ }^{30}$.

Фотографически отображая двоеверие советской эпохи, литература $1920-1930$-х годов зафиксировала и то, что в свете живых еще православных истин религия коммунизма воспринималась народом как антихристианская. Передовые герои-производственники бравируют своим антихристианством. В очерке Н. Брыкина «Провинциальная идея» рассказчик с явным удовольствием вспоминает, что в день производственного рекорда припекало «дьявольски здорово», «дьявольски хотелось помурлыкать, посвистать

перного, на которые в данном случае мы опираемся (Степанов Ю. С Константы. Словарь русской культуры. М., 1997. С. 454; Паперный $B$. Культура Два. М.: Новое литературное обозрение. С. 16-17, 165, 173).

${ }_{27}$ Беломорско-Балтийский канал имени Сталина. С. 135.

28 Эренбург И. Г. День второй. С. 359.

29 Деревенский. Деревня в современной литературе // На посту. 1923. № 4. С. 146 .

${ }^{30}$ Катаев И. Ленинградское шоссе // Красная новь. 1933. Кн. 11. C. $86-114$. под нос» песенку ${ }^{31}$. «Советский стиль работы» точно описал А. Платонов уже в рассказе 1918 года с показательным названием «Сатана мысли». Работать «как черти» призывают строителей большевики в «Соти» Л. Леонова и «Мужестве» В. Кетлинской ${ }^{32}$. В «Заметках о каучуке» курсанты, добровольно подписавшиеся ликвидировать прорыв на строительстве, и сами, без агитации, работают, «как черти» ${ }^{33}$. Исступленно, «осатанело» «осатаневшие» люди трудятся в «Дороге на океан», борются с полчищами саранчи в «Саранче» Л. Леонова ${ }^{34}$ и с плывуном в истории строительства Беломорско-Балтийского канала ${ }^{35}$. Из языковой традиции эпохи исчезает народное табу на «чертыхание». На протяжении всей жизни постоянно «чертыхался» и основоположник советской литературы М. Горький, что впоследствии дало основание исследователям говорить о том, что «у Пешкова-Горького были какие-то особенные, очень интимные отношения с чертом» ${ }^{36}$.

В речи персонажей «Новой земли» Ф. Гладкова то и дело проскальзывают присказки типа «Раньше была мамона, а теперь - коммуна», «У нас - Христос, у вас - колхоз» ${ }^{37}$ и т. д. «Катехизис» коммунаров у Гладкова также выстроен по аналогии с христианским, но христианские заповеди и добродетели в коммуне как бы вывернуты наизнанку. Смирение сменяется «зловещей кротостью ${ }^{38}$. Явно отсылающие к Священному Писанию слова председателя коммуны Ветрова: «Для меня нет ни жены, ни друга. Придет час - уничтожу жестоко и друга, и жену, и отца» ${ }^{39}$ в «Новой земле» оборачиваются не апостольским служением Богу и людям, а бесчеловечным отказом коммунарок от своих стареющих родителей, издевательством над немощной старухой. Неудивительно, что главная чер-

${ }^{31}$ Брыкин Н. Указ. соч. С. 148, 159.

32 Леонов Л. Указ. соч. Т. 4. С. 125 ; Кетлинская В. К. Мужество. Кишинев: Лит. артистикэ, 1987. С. 60, 478.

33 Зорич А. Заметки о каучуке // Красная новь. 1933. Кн. 11. С. 181.

${ }^{34}$ Леонов Л. Указ. соч. Т. 6. С. 114.

${ }^{35}$ Беломорско-Балтийский канал имени Сталина. С. 446.

${ }^{36}$ Басинский П. Горький. М.: Молодая гвардия, 2006. С. 97.

${ }^{37}$ Гладков Ф. Новая земля. С. 287.

38 Там же. С. 108

39 Там же. С. 101 
та руководителя - партийная аскеза - определяется писателем как «бездушие». Партсекретарь Банкин в повести «бесстрастный и деревянный»: «бездушно и застывшими глазами» смотрит «мимо» людей, «бездушно» говорит, «бездушно» улыбается, «жадно, но бездушно» ест ${ }^{40}$. При этом «бездушие» у Банкина — приобретенная черта, по природе же он «отзывчивый и чуткий» ${ }^{41}$, как замечает главная героиня повести Галя. В статье «Моя работа над “Энергией”» Гладков так же характеризует Мирона Ватагина: "Его холодная прямолинейность кажется бездушием...», но «Мирон, по существу, - добрый человек» ${ }^{42}$. Коммунистическая твердость оборачивается бездушием уже в «Цементе». «Пускай сердце у нас будет каменное» ${ }^{43}$ - - наставляет Даша Чумалова Полю Мелехову в главе о партийной чистке.

Писатели, выросшие в атмосфере органической веры отцов и дедов, не могли не оценивать «между строк» новую, рукотворную религию. Тема Апокалипсиса наметилась у Леонова задолго до окончания романа «Пирамида» уже в «производственной» «Соти» и «полупроизводственной» «Дороге на океан», в 1930-е годы родился и сам замысел «Пирамиды».

Может показаться, что у В. Катаева периода 19201930-х годов вопросы Бога, веры, вечного и бренного полностью отсутствовали, а метафизическая проблематика появилась в его творчестве лишь в 1965 году в повести «Святой колодец». Однако если в первой, журнальной, редакции романа «Время, вперед!» после разбора купола храма Христа Спасителя синевшее сквозь каркас «сероватое летнее небо» повествователю кажется «дылино пустынным» ${ }^{44}$, то в последующих изданиях оно делается «дико пустынным». Благодаря этой детали становится понятно, что опереточное действо на фоне производства создает писатель,

${ }^{40}$ Там же. С. 51, 53, 55, 80, 125, 141, 144, 146, 171, 173, 182.

${ }^{41}$ Там же. С. 174.

${ }^{42}$ Гладков Ф. Моя работа над «Энергией» // Октябрь. 1934. Кн. 5. C. 169.

${ }^{43}$ Гладков Ф. Цемент. М.: Худож. лит., 1967. С. 285

${ }^{44}$ Катаев В. Время, вперед! // Красная новь. 1932. Кн. 4. С. 41. в душе которого время отозвалось неожиданно острым чувством растерянности и пустоты в мире без Бога.

Такой мотив звучал уже в ранних катаевских произведениях, например в рассказе «Огонь» (1926), главный герой которого, коммунист Ерохин, «получил назначение в агитпром комитета партии для ведения антирелигиозной пропаганды... в... большом южном городе, окруженном монастырями» ${ }^{45}$. Рассказ этот в свое время вызвал острое неприятие критики. "Давая выстрел по “поповской лжи", - писала в 1932 году Б. Брайнина, - автор ничего не может ей противопоставить, кроме отчаянного содрогания перед слертью» ${ }^{46}$. В самом деле, несмотря на то что произведение выстроено в русле атеистической пропаганды и Ерохин прибегает к самым азбучным ее приемам («Где же ангелы? Где же Бог?», если их не видно в верхних слоях атмосферы), автор дает почувствовать смятение героя в решении важнейшего вопроса - о Боге. Дитя своего века, он не может ни принять истину, ни от нее отказаться. И, конечно, не случайно герои итоговой повести писателя «Сухой лиман» братья Синайские, внуки вятского протоирея, всю жизнь считавшие себя материалистами, приходят к пониманию того, как важно оставить за собой «право выполнения христианского долга» ${ }^{47}$. В 1960-1980-е годы В. Катаев лишь высказал вслух то, что порой угадывалось в подтексте самых «соцзаказных» его произведений.

Духовный климат эпохи осмысляет и И. Эренбург писатель с непростой духовной биографией, в жизни которого, помимо религиозного скепсиса, было и увлечение пантеизмом, и не осуществившееся намерение принять католичество и поселиться в бенедиктинском монастыре ${ }^{48}$. О том, как долго, планомерно прививалась новая советская вера и чем по сути она являлась, писатель не раз го-

${ }^{45}$ Kатаев B. Собр. соч.: В 5 т. М.: Худож. лит., 1956. Т. 4. С. 181.

${ }^{46}$ Брайнина Б. Творческий путь Валентина Катаева // Красная новь. 1932. Кн. 4. C. 174.

47 Литовская М. А. Социохудожественный феномен В. П. Катаева: Авторефр. дис. ... д-ра филол. наук. Екатеринбург, 2000. С. 29.

48 Эренбург И. Г. Люди, годы, жизнь: Воспоминания: В 3 т. М., 1990. T. 1. C. 14,109 
ворил позднее в своих мемуарах ${ }^{49}$. В 1930-е годы раздумья такого рода можно было доверить только герою «прошлого». В романе "День второй» крамольные мысли писателя об ущербном характере духовности, заключенной в одних лишь переживаниях за судьбу производства, излагаются в дневнике Володи Сафонова. «Я столько слышал про эти стройки - все ими захвачены. Вдруг и Володя Сафронов, после Сенек, уверует в св. Домну?.. Если это массовый психоз, то почему я не могу ему поддаться?»50 - саркастически пишет он перед поездкой в Кузнецк. Но чуда не произошло. Побывав на стройке, Володя убеждается, что, хотя «религия вообще нелепость», «все же Христос на кресте это не дядя Мартын» (так назывались мартеновские печи. - E. M.); когда же в двадцатом веке печь перестает быть просто печью, это называется не религией, а «примитивным фретишизмом» ${ }^{51}$.

В «Дороге на океан» советская религия характеризуется как «паровозная вера». "Вот еще один окрестился в паровозную веру» ${ }^{52}$, - говорит о машинисте-ударнике древняя старушка. Известный знаток религиозных и фрилософрских учений, Л. Леонов видел примитивную, фретишистскую природу новой «религиозности». Критики могли сколько угодно отрицать «паровозный» характер большевистского вероучения и утверждать, что в советской литературе нет культа машины и техники, сами произведения свидетельствовали о другом. В той же истории строительства Беломорско-Балтийского канала чекисты призывают массы верить в конкретный проект - верить в канал, верить в Сталина ${ }^{53}$.

Но в решении вероисповедных вопросов в «индустриальной» прозе встречалась и ирония другого рода. В произведениях «правоверных» писателей высмеивалось само православие как прообраз большевистской религии. Когда в романе В. Кетлинской «Мужество» на строительстве возникли перебои с поставкой продовольствия, в ответ на те-

49 Там же. Т. 3. С. 229—231, 233, 234, 252

50 Эренбург И. Г. День второй. С. 288.

51 Там же. С. 293.

52 Леонов Л. Указ. соч. Т. 6. С. 339.

${ }^{53}$ Беломорско-Балтийский канал имени Сталина. С. 232, 301, 335. атрально-торжественное предложение комсомольца Голубенко «разделить семь хлебов так, чтобы все были сыты», его товарищи шутят: «Иисус Христос!» ${ }^{54}$. Повествователь в "Романе межгорья» И. Ле словно извиняется за то, что использует библейскую лексику, порой закавычивает ее ${ }^{55}$.

Среди авторов «производственных» романов были и вчерашние эмигранты, как Г. Алексеев, для которого разработка соответствующей проблематики своего рода форма социальной реабилитации. Отвечая в 1929 году на анкету журнала «На литературном посту», писатель называл христианство «мещанством» 56 , но в его повести «На потревоженных пажитях» (1918) с симпатией показаны «православные коммунары» ${ }^{57}$. А в романе «Тени стоящего впереди» христианско-партийная проблематика так и остается до конца не решенной. Главный герой романа большевик Глушков отрицает, по его мнению, затертые, лишенные живого смысла библейские заповеди - законы, по которым живет отец его жены Василий Петрович. В романе христианская мораль действительно до неузнаваемости искажена бытом, скученностью, приспособлена под мелкие обывательские нужды. Однако вместе с тем именно апологет старого мира Василий Петрович скорбит о растоптанном революцией ближнем и призывает Глушкова к милосердию ${ }^{58}$. В 1928 году критику журнала «Звезда» Р. Ковнатору православная аргументация героев показалась более убедительной, и разбор произведения он завершил словами:

Революция кончилась - да здравствует «христианство» ${ }^{59}$.

«Производственный» роман Г. Алексеева 1933 года «Роза ветров» оставляет впечатление иллюстращии к речи Сталина на объединенном пленуме ЦК и ЦКК ВКП (б) 7 ян-

${ }^{54}$ Кетлинская В. К. Указ. соч. С. 71

55 Ле И. Указ. соч. С. 11.

56 Писатели о мещанстве // На литературном посту. 1929. № 6. С. 15.

${ }^{57}$ Струве $\Gamma$. Русская литература в изгнании. Paris: YMCA-PRESS, 1984. C. 99

58 Алексеев Г. Тени стоящего впереди // Красная новь. 1928. Кн. 4. C. $10,12-13$.

${ }_{59}$ Ковнатор P. «Тени стоящего впереди» (Роман Глеба Алексеева) // Звезда. 1928. Кн. 5. С. 156. 
варя 1933 года. «Отец народов» тогда с одобрением процитировал статью о новой Советской России американского журнала «Нейшен»:

"...путеводнылии точкали советских равнин" стали не «кресты и купола иерквей, а зерновые элеваторь и силосные башни» (курсив И. Сталина. - E. M.) ${ }^{60}$.

Писатель дважды приводит в романе эти слова Сталина:

Газеты писали о том... что путеводными точками советских равнин не являются больше кресты и купола церквей, а зерновые элеваторы, силосные башни и трубы новых заводов ${ }^{61}$.

Уже не церкви определяют ландшафт русской равнины... а трубы фабрик и заводов, готовые перевернуть следующую страницу истории человечества ${ }^{62}$.

Однако в том же романе, представляя себе людей будущего, писатель, приехавший на строительство, вспоминает начало эры Советов:

...тогда, проливая свет сквозь полустертый живот Cпасителя, с которого уже снесли голову веселье каленшики, высовывалась голова совы, пропуская вперед тяжелого корабельщика Петра, веселую Елисавет... Николая Кровавого последнего полковника «царской» крови ${ }^{63}$.

Таким образом, фоинал романа с точки зрения соцреализма получился весьма двусмысленным: большевики выступают продолжателями дела масонов. Такие параллели в ту пору были еще менее желательны, чем сравнения коммунизма с православием ${ }^{64}$.

В 1920-1930-е годы, когда формировался соцреалистический канон, идейным ориентиром в катаклизмах эпохи - часто не осознаваемым и не признаваемым - для

${ }^{60}$ Сталин И. Итоги первой пятилетки (Доклад на объединенном пленуме ЦК и ЦКК ВКП(б) 7 января 1933 г.) // Ленин и Сталин: Сборник произведений к изучению истории ВКП(б). Т. 3. М.: Партиздат ВКП(б), 1936. С. 542.

${ }^{61}$ Алексеев Г. В. Роза ветров // Алексеев Г. В. Роза ветров: Роман; Рассказы. Тула: Приокское кн. изд-во, 1988. С. 163-164.

62 Там же. С. 302.

${ }^{63}$ Там же.

${ }^{64}$ Никитин А. Л. Мистики, розенкрейцеры и тамплиеры в советской России: Исследования и материалы. М.: Аграф, 2000. С. 5, 6, 36. писателей оставалось православие. Понимание многими художниками того, что духовность, предлагаемая взамен православной вере, не может стать бытийной основой человека, проявлялось (через символические подтексты, неоднозначные ремарки, передачу опасных мыслей социально скомпрометированному персонажу) даже в таком нормативном жанре, как производственный роман. Литература, призванная «последовательно» разбивать «всякую мистику, поповщину и чертовщину», а на деле утверждавшая религию коммунизма, отобразила «двоеверие» советской эпохи, показала противоречие между френоменом новой веры и ее конечными, материалистичными основами, ее фретишистской природой; обнажила антихристианскую направленность большевистского вероучения. 